\title{
POSITIVE AND NEGATIVE ASPECT IN APPLICATION OF MAINTENANCE MANAGEMENT PHILOSOPHY
}

\author{
Hana Pacaiova* \\ Technical University of Kosice, Kosice, Slovakia \\ Juraj Glatz \\ Technical University of Kosice, Kosice, Slovakia \\ Stefan Kacvinsky \\ Technical University of Kosice, Kosice, Slovakia
}

Maintenance Management requires acceptance of basic systems approach, i.e. implementation of company goals to management goals. Well know Maintenance management philosophies (TPM, RCM, RBI) applied in order to improve processes, often remain only on the basis of the implementation of services without the need for full integration into existing management systems. Misunderstanding the nature of maintenance management leads to inefficient step, resulting in a contradiction between the goals of management and their ability to support real goals through maintenance management. Process approach in the management of maintenance is the basis for improvement in maintenance and hence achieving the required performance. KPI indicators must fulfill the criteria of accuracy and efficiency of measurement by process owners, otherwise it lead to disinformation, which results are poor management decisions, and thus a threat of requirements for continuous improvement.This article, based on practical experience, analyzes the root errors caused by maintenance management in order to apply the selected philosophy in the management of maintenance without the knowledge or lack of willingness to accept a systemic approach to maintenance management.

Key words: Risk Management, FMEA, management system, KPI, implementation,

\section{INTRODUCTION}

In industrial practice the basic effort is to reduce costs and increase profits. Often it happens by the changes, respectively manufacturing processes innovation. But we always talk about technological processes, which effort is to reduce their energy consumption, while taking into consideration the entire life cycle of technology systems, as well as selection of suitable maintenance strategy in order to minimize losses and waste.

Maintenance as combination of all technical, administrative and management activities during the object's life cycle in order to maintain or restore it to a state where it can perform required function, has an impact on safety, environment, product quality, total profit, respectively loss of company. As follows from the definition of [03], maintenance is not only the task of ordinary employees working on the maintenance position, but it is mainly management role into which it is necessary to include each employee of the company. Different management philosophies help to monitor targets companies, often with the support of specific management systems (quality, environment, safety, information safety). It often happens that these systems do not correspond with the goals of maintenance management and have little or even controversial impact on its management.

\section{BASE PRINCIPLE OF SYSTEMATIC APPROACH IN MAINTENANCE}

Management system is a set of interconnect processes that brings to the organization increased efficiency and effectiveness in achieving determined objectives.

Total Quality Management - TQM (which evaluation is based on model EFQM - Model Excellencies) define basic principles of management system, namely [04]: 
1. Customer focused organization

2. Leadership and teamwork

3. Development and Involvement of people

4. Process orientation

5. Social Responsibility (environment)

6. Continual Improvement

7. Result Measurement

8. Mutually beneficial supplier relationships.
Process is defined as a set of activities using resources and regulations to enable the transformation of inputs into outputs, as shown in Figure 2. The process approach represents identification, interaction and process control in such way that the output of one process is presented as input to the next process. This relation can be understood as the certain interconnection of process.

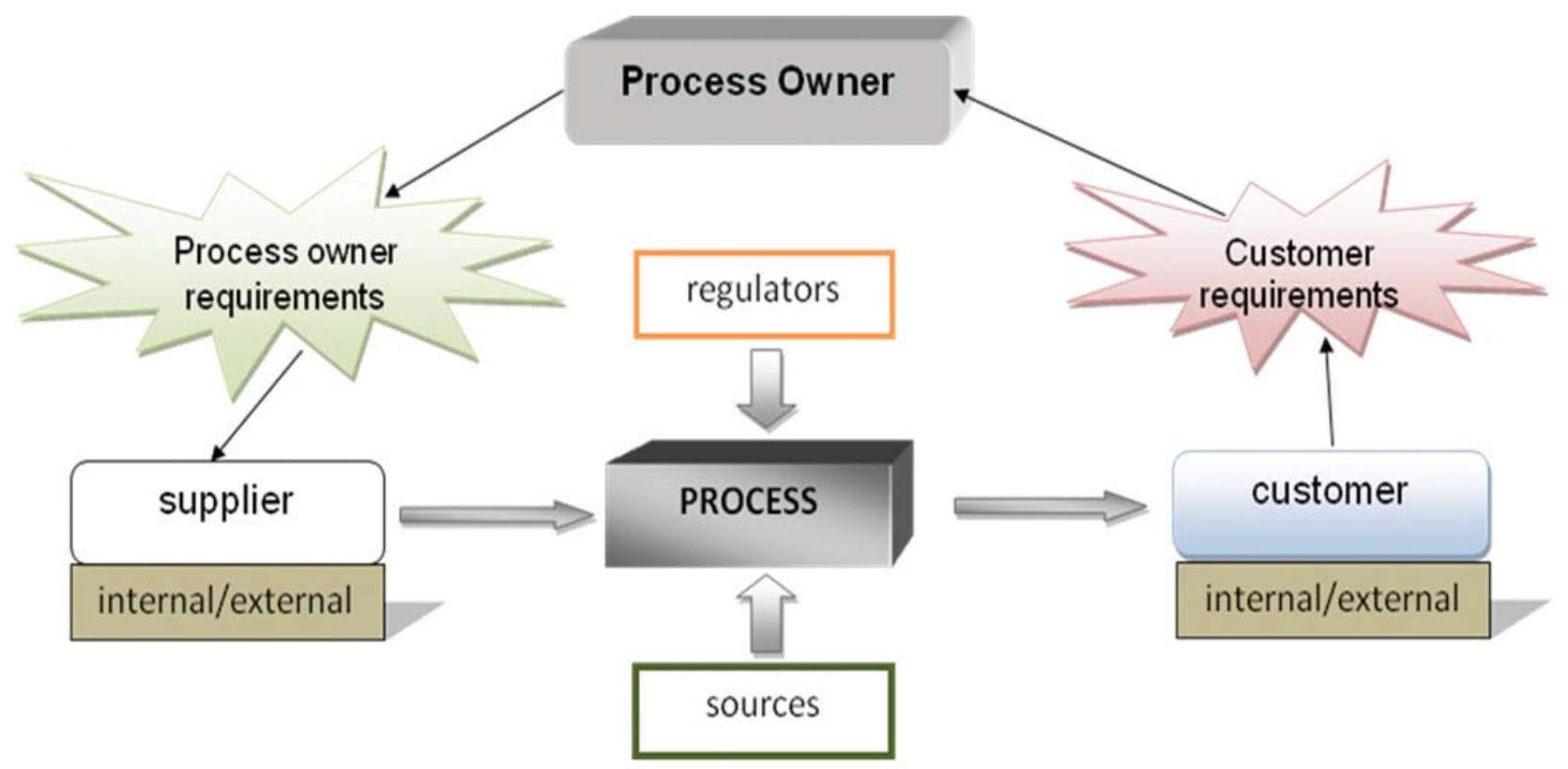

Figure 1: The base principles of process [04]

Continual improvement of the organization's performance needs to be taken as a major goal of any kind of organization!

\section{Maintenance Management \& Systematic Approach}

Maintenance terminology (EN 13306) understands maintenance as a process which includes management, administrative and technical activities in order to maintain or restore equipment into the required state. In the introduction requirements on safe and quality maintenance are pointed out. Into account are also taken requirements on control of environmental impacts and costs effectiveness.

In some literatures states, that maintenance costs are in range from $20 \%$ to $35 \%$ of production costs. More than $25 \%$ of accidents in underground mines happen during maintenance. More than $10 \%$ of loss of production time happens due to corrective maintenance, etc. [05, 02].

Each of these indicators appeals to "backlog" (reserves), which results not only from the socalled: direct maintenance costs but mainly from so-called: induced costs, which result from deficiency of maintenance planning.

It is important that maintenance management is aware of not only the principles of system's management, but also the tools and sources for strategy decision and maintenance activities based on analytical approaches and methods, such as:

- Root Cause Analysis (RCA)

- Failure Modes and Effects Analysis (FMEA/FMECA - Criticality)

- Fault Tree Analysis (FTA)

- Hazard and Operability Analysis (HAZOP)

- Human Error / Reliability Analysis (HEA/HRA).

Certain methods are indicated as standard analytical methods and are usually accompanied by the criticality analysis, i.e. analysis of critical equipment which criteria correspondent to those areas where management of the company points out steps by its policy or through company goals (sources and responsibility).In these areas 
will be used precautions to prevent unwanted uncontrolled loss (safety, environment, quality, information safety, cost, etc.

Maintenance strategies (see Figure 2) are therefore focused on prevention of the failure mode, where failure of equipment has its "critical" impact on desirable results (goals) or at a "tolerable" risk is a maintenance strategy focused on repair in case of failure occurs.[08].

We know two basic maintenance strategies:

- Preventive - focused on prevent of failures

- Corrective - focused on efficient repair of equipment after the failure occurrence.

Preventive strategy in a simplified context may be scheduled "fixed" by time, mileage, cycles, etc., or may be performed when "monitoring state" of equipment would lead to an accident (we call it predictive maintenance strategy).
Criteria of choosing the maintenance strategy in the planning phase are specified areas of seriousness losses, as a result of failure - i.e. loss of equipment function, and may be threat of set goals of the company. It is mainly in areas of:

- safety of company employees,

- public safety close to company surroundings,

- threat of environmental requirements,

- loss of production quality or delivery delay ,

- loss of company property or foreign ownership,

- the high costs spent on equipment repair in case of failure,

- losses affecting the region's economy or economy of all society.

Nowadays in companies we can also often find criteria such as "loss of company image" as a result of major industrial accidents.

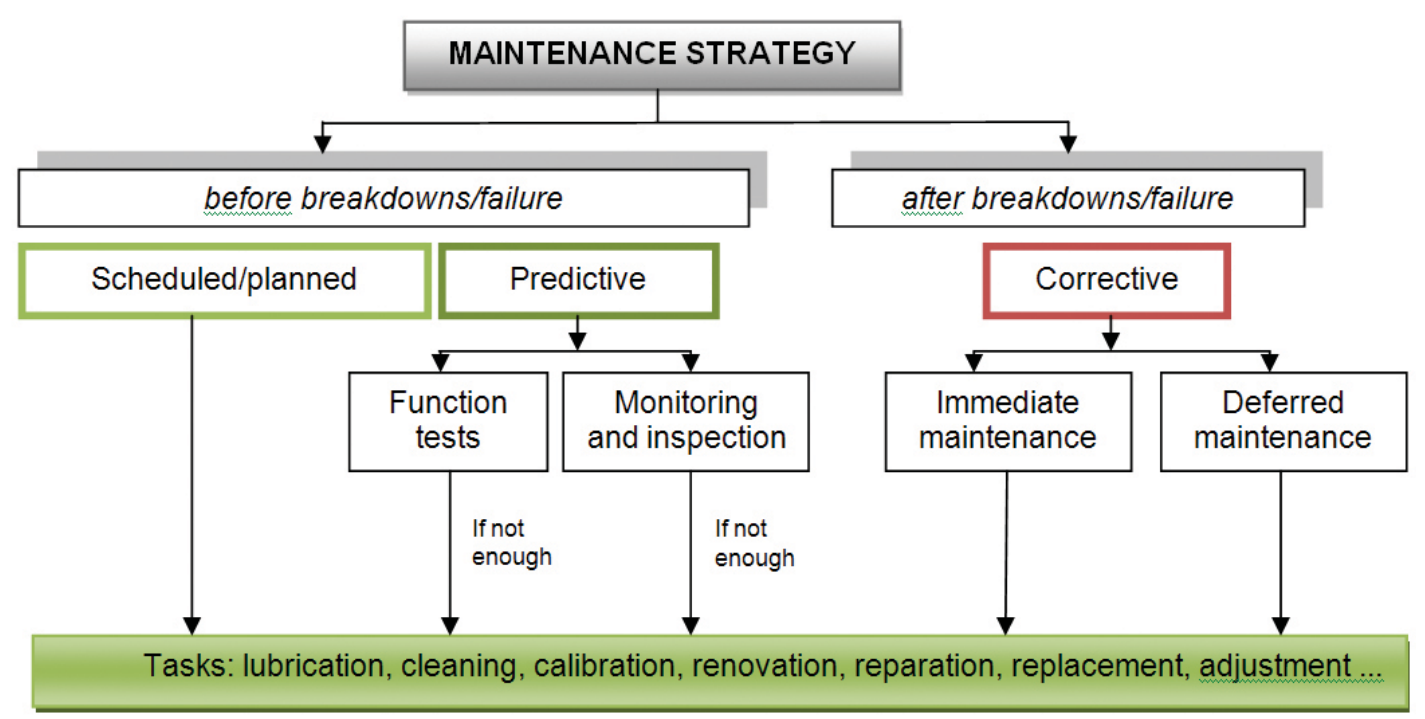

Figure 2: Maintenance strategy and maintenance tasks [05]

Assurance of the company goals is possible only if there are provided sources and support from company management, so that these goals could be transformed into maintenance management goals, as shown in Figure 3.

Planning in maintenance management requires the application of such analytical methods which are able to ensure adequate support (maintenance support) for the implementation of planned activities based on the specified management goals (Maintenance Task Analysis) [05].

Nowadays in the maintenance management are well known mainly the following philosophies, which are completely or with minor editing suitable for most industrial companies, as described in Table 1 [05]:

- TPM - Total Productive Maintenance developed in Japan as a conception of maintenance management including all departments, i.e. from management to manufactory, controlling support of company's maximum productivity based on increase principle of production equipments effectiveness. Author of the TPM conception is Seichi Nakajima, who gradually studied systems for preventive maintenance in 50tees a 60tees years (Preventive Maintenance) in the USA a Europe. 
- RCM - Reliability Centered Maintenance presents systematic approach for identification of effective and preventive equipments and their elements maintenance activities according to specific procedures and proceedings based on intervals defined to perform single maintenance activities. It was developed when maintaining planes of Boeing 747 a 777 type in the USA and in 1960 1970 it was officially elaborated as a base for maintenance management mainly in aircraft industry (technical standard SAEJA1011).

- RBI - Risk Based Inspection is an assessment and risk management process, which evaluates loss risk of pressure equipment's content influenced by materials deterioration. This risk is controlled by equipment's inspection. That means that the priorities of maintenance activities are defined according to analyses and risk assessment.

- RIMAP - Risk Based Inspection and Maintenance Procedures is a result of European project (5 framing project EU 1998-2002), which goal was to develop unitized optimal approach to inspection and maintenance activities based on risks assessment in industrial companies).

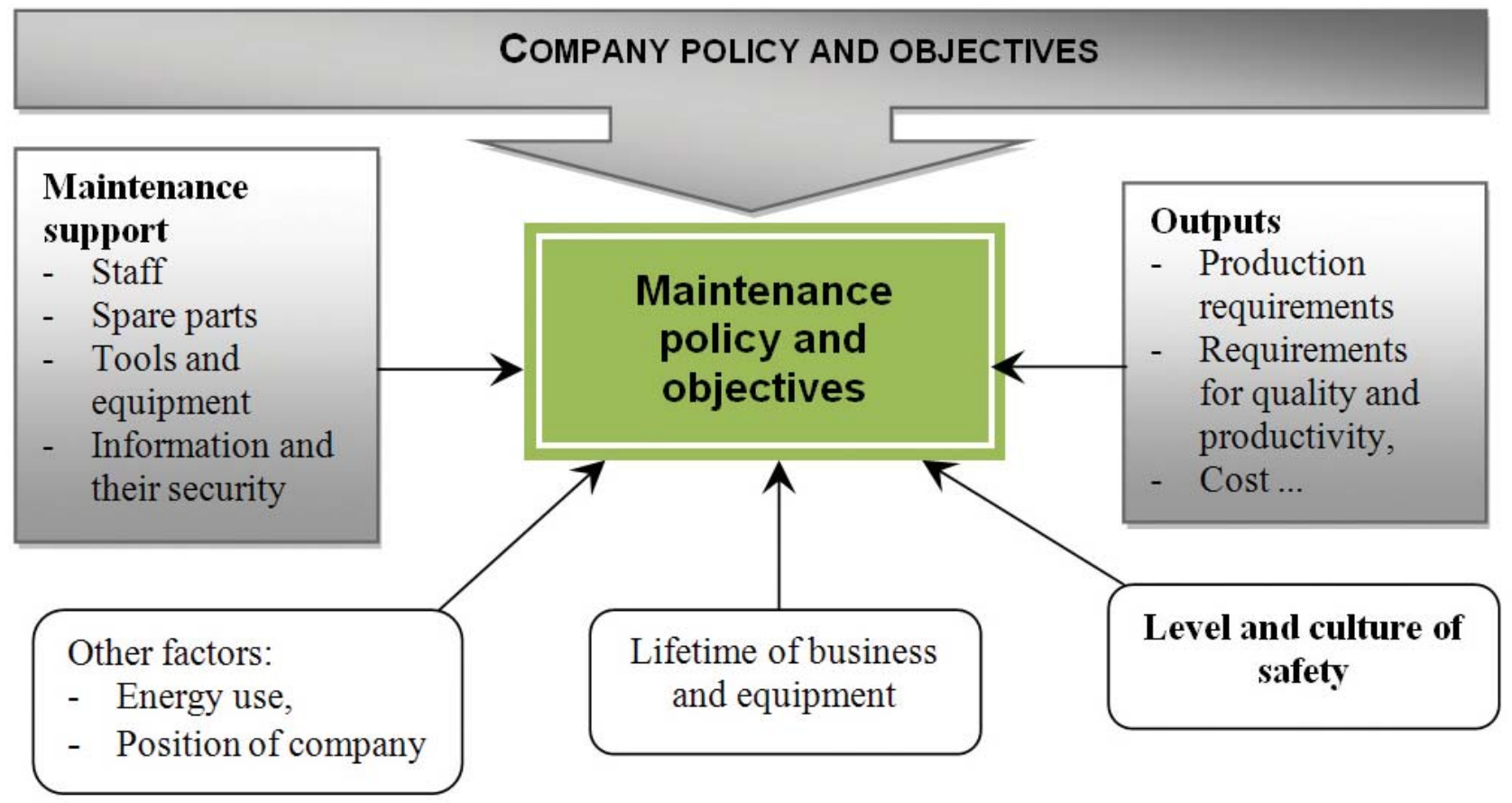

Figure 3: Factors influencing of maintenance goals

Table 1: Examples of Maintenance philosophy application [05]

\begin{tabular}{|c|c|c|c|}
\hline & RCM & TPM & RBI \\
\hline $\begin{array}{c}\text { USED IN PHASE OF } \\
\text { LIFE CYCLE }\end{array}$ & $\begin{array}{c}\text { Design, Operation and } \\
\text { maintenance }\end{array}$ & $\begin{array}{c}\text { Operation and } \\
\text { Maintenance }\end{array}$ & $\begin{array}{c}\text { Design, Operation and } \\
\text { maintenance }\end{array}$ \\
\hline \hline $\begin{array}{c}\text { MAIN USED IN } \\
\text { INDUSTRY }\end{array}$ & $\begin{array}{c}\text { Chemical, petrochemical, } \\
\text { gas, nuclear }\end{array}$ & $\begin{array}{c}\text { Automotive, brewing, } \\
\text { food, manufacturing }\end{array}$ & $\begin{array}{c}\text { Chemical, petrochemical, } \\
\text { gas, nuclear }\end{array}$ \\
\hline CRITICALITY FILTER & ABC & ABC & ABC \\
\hline OBJECTIVE & Max. reliability and safety & $\begin{array}{c}\text { Max. effectiveness and } \\
\text { availability }\end{array}$ & $\begin{array}{c}\text { Health, safety } \\
\text { and environment }\end{array}$ \\
\hline \hline MAIN METHODS & FMEA, Ishikawa & OEE, PM & $\begin{array}{c}\text { FTA, ETA, social } \\
\text { risk assessment }\end{array}$ \\
\hline
\end{tabular}




\section{Maintenance management and measurement}

Fundamental aspect in order to achieve goals is to define measurable indicators that can be measured and evaluated in long term period. Nowadays there is trend in many companies to define the so-called key indicators / performance indicators (KPI - Key Performance Indicator) [10] for individual processes, eventually activities, which evaluation is used not only for activities improvement but also for reciprocal comparison between companies with similar activities or processes (so-called benchmarking). An example of such an approach is to define criteria for top - the best evaluation in Asset management, as shown in Table 2.

Table 2: Performance evaluation according to top - the best criteria in Asset management [10]

\begin{tabular}{|c||l|}
\hline Achieved Class & Performance values \\
\hline The Best & - $88 \%$ overall equipment effectiveness (OEE), \\
$20 \%$ of total value & - $2 \%$ corrective maintenance, \\
& - $25 \%$ of assets profitability. \\
\hline $\begin{array}{c}\text { Average } \\
50 \% \text { of total value }\end{array}$ & - $88 \%$ overall equipment effectiveness (OEE), \\
& $-25 \%$ of assets profitability. \\
\hline $\begin{array}{l}\text { Under average } \\
30 \% \text { of total value }\end{array}$ & - $75 \%$ overall equipment effectiveness (OEE), $18 \%$ corrective maintenance, \\
& $-10 \%$ of assets profitability. \\
\hline
\end{tabular}

The most common problem in society, despite implementation of quality management system, is insufficient monitoring and evaluation of potential losses. Focusing on continuous improvement leads to the use of many tools only by formal way. Making a map of processes, searching for failures by analyzing the causes and consequences (FMEA / FMECA - Failure Mode and Effect Analysis / Failure Mode and Criticality effect analysis), SWOT analysis (analysis the weaknesses and strengths), the $5 \mathrm{~S}$ method, often means only the way of positive assessment for auditors, while lacking a clear connection with the activities and identification of their impact on specified company goals, not even mention the responsibility.

Maintenance Performance is the result of the utilization of resources in providing actions to retain an item in, or to restore it to a state in which it can perform the required function [07]. It can be expressed as an achieved or expected result.

The Maintenance performance is dependent upon both external and internal influencing factors such as: location, culture, transformation and service processes, size, utilization rate and age and is achieved by implementing corrective, preventive and improvement maintenance, using labor, information, materials, organizational methodologies, tools and operating techniques.
Maintenance performance is an outcome of complex activities which can be evaluated by appropriate indicators to measure both the actual and expected results [06].

In maintenance it is even more expressive that it is necessary to apply risk management methods when making decisions and controlling maintenance activities [07].

Index of overall equipment effectiveness (OEE) is defined as combination:

$O E E=A \times P \times Q \times 100 \quad[\%]$,

Where:

A - Availability of equipment [-],

$P$ - Performance [-],

Q - Quality measure of produced production [-].

On one hand this index expresses effectiveness, which is succe1ss in achieving functionality (alert - to be able to fulfill required function in a specified time) efficiency and required quality of production of production facility. On the other hand, from the point of "risk analysis", it enables to define all of possible threats when achieving specified goals (objectives) - see Table 3. 
Table 3: Maintenance Management Objectives vs. OEE

\begin{tabular}{|c|c|}
\hline Parameter & Hazards \\
\hline A-Alert & $\begin{array}{l}\text { - unplanned machines breakdowns, } \\
\text { - too many planned pauses } \\
\text { (inadequate to machine condition), } \\
\text { - long - term repairs (MTTR), } \\
\text { - insufficient planning and spare parts assurance (MTL), } \\
\text { - bad quality of machine repairs (repeated controls), }\end{array}$ \\
\hline$P$ - Performance & $\begin{array}{l}\text { - insufficient care of machines } \\
\text { (setting up, machine lubrication, cleaning, etc.), } \\
\text { - bad work organization, } \\
\text { - bad quality of purchased parts } \\
\text { (insufficient performance, capacity, etc.), }\end{array}$ \\
\hline Q-Quality & $\begin{array}{l}\text { - insufficient care of machines } \\
\text { (setting up, machine lubrication, cleaning), } \\
\text { - bad adjustment of machinery, } \\
\text { - operators failures etc. }\end{array}$ \\
\hline
\end{tabular}

Theoretically the OEE could be used as a part of expression the $\mathrm{RC}$ index of total risk rate as followed:

$R C=$ OEE $\times S \times E \times 100 \quad[\%]$,

Where:

$\mathrm{S}$ - safety margin expressed as a percentage of the possible injury on the specific equipment to the total potential injuries in a society,

$\mathrm{E}$ - environmental requirements rate, as the ratio of predicted environmental aspects to the total monitored aspect of society.

In the maintenance management is the structure of key performance indicators described in standard EN 15341.

\section{Summary of positive and negative aspects when implementing systematic approach in maintenance management}

Another tool to measure the effectiveness and efficiency of maintenance management is maintenance audit. It can be used for reassessment maintenance processes and effectiveness of selected strategies to the requirements assigned for achieving specified goals.

Various advantages and disadvantages of Effective Maintenance Management have been described in the document above. Among the advantages when implementing a systemic approach into maintenance management belong mainly:

- compliance with elements / requirements of other management systems (for example the use of FMEA),
- clearly specified participation in achieving goals,

- pointing out the importance of planning stage in maintenance - selecting and verifying suitable strategies,

- possibility of measurement and control,

- effective costs control,

- higher competitiveness.

Among the disadvantages belong these aspects:

- lack of understanding (ignorance) of analysis methods (planning stage) - selection only some of them without understanding their contribution,

- understanding concepts as a tool for reducing the number of maintenance workers, or maintenance costs reduction,

- expected return quickly without sufficient support,

- inappropriate way of management,

- inaccurate specification of KPI structure and the need for measurements in maintenance processes,

- difficulty in educating maintenance staff, as well as operators (for example. TPM),

- insufficient communication and management support.

- bad corporate culture. 


\section{CONCLUSION}

To achieve strategically important goals of the company, optimize costs spent on life cycle of equipment it is impossible to apply other maintenance management system than system based on consistent analysis of equipment criticality and their risks. Planning maintenance strategies and performance of maintenance activities can bring required effect only if it is based on system tools and tools assigned for risks assessment of run and maintained technical equipment. Dynamic maintenance program must takes into account any operation changes and equipment conditions that are part of risk analysis and its goal must be process of continual improvement.

\section{ACKNOWLEDGEMENTS}

This research has been supported by the grant of Ministry of Ministry of Education, Science, Research and Sport of the Slovak Republic „Research centre of the science of integration system conjunction of renewable energy sources - VUKONZE", ITMS 26220120064.

\section{REFERENCES}

1) Batalović V., Danilović D., Živković M., Model od oil and gas pipeline rinsing using the fluid flow, Journal of Applied Engineering Science, 9(2011)1, p.237-242

2) DHILLON, B.,S, (2008) Mining Equipment Reliability, Maintainability and Safety, Springler, USA, pp.115 - 124, ISBN 978-1-\$84800-287-6.

3) EN 13 306: 2001 Maintenance terminology. Bratislava: vyd. SUTN, 2006, 55pp.

4) Nenadál J, and col., Modern Quality Management. Management Press, Praha 2008, pp. 377, ISBN 978-80-7261-186-7.

5) Pačaiová H, Kacvinský Š, Grenčík J (2011) Trends in Maintenance in Automotive industry. In: DIAGO 2011 : Technická diagnostika strojů a výrobních zařízení : 1.- 2.2.2011, Rožnov pod Radhošt'ěm. - VŠB TU Ostrava, 2011, pp. 226-232, ISSN 1210 - 311X.

6) Pačaiová $H$, Nagyová $A$, Namešanská J. (2011) Advantages and Disadvantages of $\mathrm{KPI}$ in Risk Management Process. In: 3rd iNTeg-Risk Conference \& 20th SRA - Europe Meeting : book of abstracts : Stuttgart, 6-8 June 2011. - Stuttgart : Steinbeis-Edition, 2011, pp. 38. ISBN 978-3-941417-65-6.

7) Pačaiová H, Sinay J, Glatz J, (2009) Safety and risk of technical systems. SjF TU of Kosice, 2009. 246 pp. ISBN978-80-553-0180-8.

8) Pačaiová H, Sinay J, Kacvinský Š (2010) Maintenance control and risk management. In: Reliability, Risk and Safety: back to the future : ESREL 2010 : European Safety and Reliability Conference : 5 - 9 september 2010, Rhodes, Greece. - London: Taylor \& Francis, 2010, pp. 1474-1480. ISBN 978-0-415-60427-7.

9) Rakyta M, (2010) Total productive maintenance, system for assure performance, quality and safety, ŘíZENÍ A ÚDRŽBA průmyslového podniku, internet: http:// udrzbapodniku.cz/index.php?id=47\&tx ttnews[tt_news] $=3586 \& t x$ ttnews[backPid] $=$ 1261\&cHash $=e 3 c e 3 b 239 c$.

10) Shah M, Littlefield $M,(2009)$ Asset Performance Management, November 2009, Aberdeen Group.

Paper sent to revision: 28.05.2012.

Paper ready for publication: 20.06.2012. 